\title{
New directions in the treatment of degenerative disc disease
}

\author{
Nowe kierunki leczenia choroby zwyrodnieniowej krążków \\ międzykręgowych
}

\author{
Robert Gasik \\ Department of Neuroorthopaedics and Neurology, Department of Rheumatic Orthopaedics, Institute of Rheumatology, Warsaw, Poland
}

Key words: discopathy, treatment, regeneration.

Słowa kluczowe: dyskopatia, leczenie, regeneracja.

\begin{abstract}
Sum mary
Degenerative lesions in intervertebral discs rank among the most common causes of spinal pain syndromes. Conservative treatment, pharmacotherapy and rehabilitation focus on the elimination of pain symptoms without addressing the underlying cause of the pain. Surgical techniques applied to date have, in turn, eliminated the cause of the pain while failing to halt the degeneration process affecting the discs. The future of the treatment of degenerative disc lesions lies in methods affecting the nutrition, improving the hydration and stimulating the regeneration of intervertebral discs, as outlined in the present study.
\end{abstract}

Spinal pain syndromes affect ca. $80 \%$ of populations in industrialized countries. In a vast majority of cases, clinical symptoms arise, either directly or indirectly, as a result of degenerative lesions in intervertebral discs (IDs).

The treatment of degenerative changes in the IDs is typically based on conservative methods including pharmacotherapy and rehabilitation. The aim of conservative treatment is to remove symptoms of degenerative disease. Patients with progressive symptoms of degenerative disc disease (DDD) are referred for surgical therapy. None of the therapeutic methods enumerated above, however, influences the progression of the disease in the IDs or offers the possibility of restoring normal ID function. In other words, the most common treatments for DDD concentrate on eradicating the symptoms without dealing with their causes. The gap in DDD treatment

\section{Streszczenie}

Zmiany zwyrodnieniowe krążków międzykręgowych to jedna z najczęstszych przyczyn zespołów bólowych kręgosłupa. Leczenie zachowawcze, farmakoterapia i rehabilitacja są ukierunkowane na zniesienie objawów bólowych, ale nie wpływają na ich przyczynę. Dotychczasowe techniki w leczeniu operacyjnym znosity natomiast przyczynę bólu, nie wpływając jednak na hamowanie procesu degeneracyjnego krążków. Przyszłością w leczeniu zmian zwyrodnieniowo-degeneracyjnych krążka międzykręgowego są omówione w artykule metody oddziałujące na jego odżywienie, poprawę uwodnienia i regenerację.

is being filled by new therapeutic techniques aiming to achieve ID regeneration.

The current research on DDD covers four major areas: application of biomolecules, cell implantation, gene therapy and use of biomaterials. Each of these techniques should have an effect on specific degenerative processes taking place in the IDs. The processes go through three main stages. In the initial period, the equilibrium between catabolic and anabolic processes within the IDs becomes unstable; at this stage, potentially the best therapeutic effects can be achieved with methods that seek to restore the disturbed equilibrium through the supply of biologically active substances, exhibiting a trophic activity. The methods include the administration of growth factors or gene therapy which aims to achieve gene expression and stimulate the production of biomolecules. The second period is associated with 
structural lesions such as a decrease in cell count and a reduction in water content in the IDs. In this phase, the best effects can be obtained by cell implantation. In the final period, when pathological changes alter the structure of the IDs and compromise their function, the best therapeutic solution is to use methods based on tissue engineering [1].

Intervertebral disc metabolism can be affected through the injection of biologically active compounds directly into the nucleus pulposus of the pathologically altered disc. In contrast, growth factors are administered to maintain the cell count in the nucleus pulposus and in the anulus fibrosus. In addition, growth factors can potentially induce the migration of cells initially located outside into the ID. A higher activity of ID cells improves the metabolism and leads to a partial regeneration which manifests itself as an increased production of collagen types I and II, proteoglycans and other substances. Studies investigating growth factors have encompassed various animal models of DDD, and examinations of patients suffering from degenerative intervertebral disc lesions. The studies have been conducted with many growth factors, with varying degrees of success. One of the investigated factors was recombinant human growth and differentiation factor-5 (rhGDF) [2] which belongs to a group of morphogenetic bone proteins. In tissue culture studies, rhGDF has been shown to increase the concentration of collagen II and proteoglycans. Animal model studies of rhGDF have, in turn, demonstrated an increasing water content and a growing interlamellar dimension in the IDs. There have also been studies focusing on the application of growth factors such as osteogenic protein-1 (OP-1) [3]. Osteogenic protein-1 also belongs to the group of morphogenetic bone proteins. Its anabolic effect on the IDs in animal model studies has manifested itself as the halting of the process of decrease in intervertebral disc height, and an improvement in biomechanical characteristics of the pathologically altered ID, i.e. its elasticity [4]. Good effects in animal model studies have also been obtained following the administration of platelet-rich plasma (PRP) into the IDs affected by the degenerative process. Platelet-rich plasma application has resulted in the halting of the process of decrease in intervertebral disc height and reduction in the number of cells involved in injury response and leading to damage of the ID structure [5]. Other agents investigated in studies of ID regeneration include bone morphogenetic protein 2 (BMP-2), transforming growth factor $\beta$ (TGF- $\beta$ ), insulin-like growth factor 1 (IGF-1) and basic fibroblast growth factor (bFGF).

The next step in supporting ID regeneration is the implantation of cells, usually autologous chondrocytes and mesenchymal stem cells (MSC). Studies have been conducted both in animal models and in DDD patients, aiming to supplement the missing pool of cells or replace them. The implantation of chondrocytes harvested from the IDs, multiplied and used for therapy has also been shown to increase the concentration of proteoglycans and collagen types I and II. The procedure has resulted in increased water content and a secondary improvement of ID elasticity. The implantation of autologous chondrocytes is already used in clinical practice. Unfortunately, the method has numerous shortcomings related to the manner of cell harvesting (surgical methods) and the reported reduced ability of the cells to produce biomolecules, e.g. collagen type II of autologous cells [6]. At present, a great interest is focused on allogeneic cells of mesenchymal origin. These cells can be harvested very easily from a patient's adipose tissue or bone marrow and umbilical blood. The cells also have a potential capacity to produce the extracellular matrix present in the IDs. Unfortunately, the application of this cell line for regeneration therapy entails a number of drawbacks. One of them is the lack of adequate knowledge about controlling the process of differentiation of mesenchymal cells into cells which are naturally found in the IDs, which can prevent the restoration of ID structures. The current state of knowledge gives rise to a range of errors resulting, for example, in the undesirable differentiation of mesenchymal cells into bone cells instead of chondrocytes [7]. What is more, the oncogenetic potential of MSCs is unknown.

Intervertebral disc regeneration can also be achieved with gene therapy. In the future, the primary task of gene therapy will be to compensate for genetic defects which increase the susceptibility to DDD. The currently ongoing studies evaluate the extent and stability of expression of genes responsible for changes in cell metabolism which are expected to improve the composition of the extracellular matrix of the nucleus pulposus and the anulus fibrosus. In other words, the main goal of gene therapy in the treatment of DDD is to provide cells with new phenotypic properties. There have been studies investigating the delivery of growth and differentiation factor-5 in in vivo models, resulting in changes in their expression persisting for many weeks [8]. The studies have also encompassed genes for IGF-1, BMP-2, TGF- $\beta$ and latent membrane protein 1 (LMP-1). Gene therapy usually involves the use of adenovirus carriers (vectors). Adenoviruses currently ensure the best expression of the delivered genetic material, though the immunogenicity potential of these virus vectors in human therapy also needs to be taken into consideration.

In addition to methods of biological treatment of DDD, the knowledge of biomaterials is steadily expanding. Biomaterials are necessary for ensuring the correct 
course of regenerative processes in advanced stages of DDD. In such cases, biomaterials serve to retain growth factors within the disc and slowly release them - or control the maturation of MSCS. Another function of new biomaterials is supporting ID regeneration, e.g. by delivering drugs, proteins or genes. Biomaterials are also used for two- or three-dimensional restoration of the damaged and/or missing ID structure which is occupied by implanted cells. This solution will enable complete reconstruction of the ID structure. Scaffolds of this type are already obtained from natural substances which are neutral to body cells, e.g. agarose or collagen [9]. The expansion of tissue engineering focused on ID diseases is currently contributing to the development of such materials ensuring that the extracellular matrix will accumulate in accordance with a predetermined three-dimensional pattern. This is required for restoring a correct fibre structure, e.g. in collagen fibres arranged in the anulus fibrosus of the intervertebral disc [10]. At present, studies of this type concentrate on polyurethane scaffolds which display a very high degree of biointegration with ID tissues.

Although the development of ID regeneration methods is now acquiring great momentum, many questions still remain unanswered. For example, it is not clear how to establish the best candidates for such therapy, how to optimally adjust a method to lesions found in additional examinations (e.g. MRI), how to control processes of maturation of cells administered into the IDs, and how to evaluate the costs of such treatment. It is nevertheless expected that the majority of therapeutic methods described above will be available to patients in the foreseeable future.

The author declares no conflict of interest.

\section{References}

1. Maidhof R, Alipui DO, Rafiuddin A, et al. Emerging trends in biological therapy for intervertebral disc degeneration. Discov Med 2012; 14: 401-411.

2. Chujo T, An HS, Akeda K, et al. Effects of growth differentiation factor-5 on the intervertebral disc - in vitro bovine study and in vivo rabbit disc degeneration model study. Spine 2006; 31: 2909-2917.

3. Masuda K, Imai Y, Okuma M, et al. Osteogenic protein-1 injection into a degenerated disc induces the restoration of disc height and structural changes in the rabbit anular puncture model. Spine 2006; 31: 742-754.

4. Miyamoto K, Masuda K, Kim JG, et al. Intradiscal injections of osteogenic protein-1 restore theviscoelastic properties of degenerated intervertebral discs. Spine J 2006; 6: 692-703.
5. Gullung GB, Woodall JW, Tucci MA, et al. Platelet-rich plasma effects on degenerative disc disease: analysis of histology and imaging in an animal model. Evid Based Spine Care J 2011; 2: 13-18.

6. Hegewald AA, Endres M, Abbushi A, et al. Adequacy of herniated disc tissue as a cell source for nucleus pulposus regeneration. J Neurosurg Spine 2011; 14: 273-280.

7. Vadalà G, Sowa G, Hubert M, et al. Mesenchymal stem cells injection in degenerated intervertebral disc: cell leakage may induce osteophyte formation. J Tissue Eng Regen Med 2012; 6: 348-355.

8. Liang H, Ma SY, Feng G, et al. Therapeutic effects of adenovirus-mediated growth and differentiation factor- 5 in a mice disc degeneration model induced by annulus needle puncture. Spine J 2010; 10: 32-41.

9. Saad L, Spector M. Effects of collagen type on the behavior of adult canine annulus fibrosus cells incollagen-glycosaminoglycan scaffolds. J Biomed Mater Res 2004; 71: 233-241.

10. Nerurkar NL, Mauck RL, Elliott DM. Modeling interlamellar interactions in angle-ply biologiclaminates for annulus fibrosus tissue engineering. Biomech Model Mechanobiol 2011; 10: 973-984. 